\title{
Ancient Egyptian influences in Coptic wall paintings
}

\author{
Aya Gaber Haggagy \\ Aya7hassan@hotmail \\ Faculty of Tourism and Hotels \\ El-Minia University
}

\section{Ancient Egyptian influences in Coptic wall paintings}

\begin{abstract}
The art of wall painting has been deeply influenced by rituals and religious of mankind, this can be guided by the ancient Egyptian art which was exclusively Funerary. The ancient Egyptian Architecture and art, which we are considering were the fruit of religious beliefs.

Wall painting had a great, important role in the development and establishment of Faith in Egypt, The concept of wall painting developed from a sample cover for the walls to a complex representation for the new Christianity, and wall painting in Coptic art demonstrated the ability to highlight the aesthetic elements in a smooth way, but the most impressive thing in Coptic art is that the variety of treatment of the same subject.
\end{abstract}


This paper is about the ancient Egyptian influences in Coptic wall painting. The aim of this study is to determine the depicting styles, to classify the different stages of the Coptic wall painting.

\section{Keywords}

Cupric wall painting, ancient Egyptian art, Coptic art.

\section{Introduction}

As an art, it is regarded as a result of nature and environments, and the main traits of any art must be originated from the customs and traditions of its people and inspired by the natural and geographic phenomena of the country. Any art is originated from circumstances of life and is formed according to its location and heritages. ${ }^{1}$ Thus, it is not natural to argue that the artist had watched the ancient monuments of Egypt that stood throughout centuries with their contents of architects, temples, tombs, coffins and decorations, with their implications of artistic schools, without leaving any impacts in his works throughout the different artistic stages in Egypt, including the Christian stage. ${ }^{2}$ So that, the artistic ancient Egyptian influences had a key role in forming the traits that attached to the Christian art in Egypt, as the arts from the dawn of Christianity cared with the ancient Egyptian's influence on their artistic and architectural achievements. ${ }^{3}$

Meanwhile, some archaeologists, such as Weasel, deny the ancient Egyptian influence, instead, they originated the influences of the Egyptian products during the Christian era to Hellenistic elements. Weasel said" This art is a copy of the Byzantine art, the Egyptian artist made it for the Greeks, or made by Greeks". ${ }^{4}$ Farid argued that the Hellenistic and Roman traditions impaired largely the ancient Egyptian influence that almost disappeared. ${ }^{5}$ While Voliach argued that, the Hellenistic art, itself, copied many traits from the ancient Egyptian art, the art of Coptic ' ancestors.

However, the Egyptian who managed to resist the foreign influences in all cultural fields by adopting them and then subjected to his own circumstances, cannot lose this feature suddenly, which is considered of his main features and being owned with his civilization to the neighboring nations after adopting the Christianity. ${ }^{6}$

\section{Literature Review}

\section{The location of mural paintings inside the Coptic Church}

$$
\begin{aligned}
& 1 \text { عبدالرحمن السروجي، در اسة علاج وصيانة الايقونات القبطية تطبيقا علي ايقونات من بعض مناحف وكنائس و اديرة }
\end{aligned}
$$

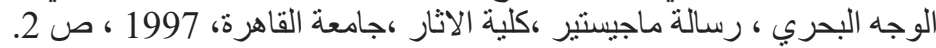

$$
\begin{aligned}
& 2 \text { مني بدر، اثر الفن القبطي علي الفن الاسلامي في التحف المنقولة، رسالة ماجستير ، كلية الاثار ،جامعة القاهرة، } \\
& \text { 45 1980، 1980 } \\
& 3 \text { باهور لبيب، العصور المسيحية الاولي، الفن القبطي، موسوعة محيط الفنون، القاهرة، 1971،ص. } 1939 .
\end{aligned}
$$

4 Weasel, K, L'art Copte, L'art Antique de La Basse Époque en Egypt, Brussels 1964, p.83.

5 فريد شافعي، العمارة العربية في مصر الاسلامية،القاهرة، 1934 ،ص 1943.

${ }^{6}$ Badawy, A., L'art copte. Les influences Égyptiennes d'art copte, Le Caire, 1948, p.1. 
Early Christians were just like the ancient Egyptians in several beliefs; they congregated sometimes in tombs because they wanted to be near the spirits of their beloved ones or gathered in private houses. The mural paintings at first appeared in tombs during the second and the third century A.D. the surviving Coptic mural paintings dating back to the first three centuries A.D. are very rare in comparing to those of later periods the main source of information about them, the paintings were inspired from the Old and the New Testament with supplement by religious symbols. ${ }^{1}$

The early Coptic mural paintings were located in churches and monasteries in special sites to serve their religious function. The figurative motifs were found usually on walls, vaults and columns. While, the complex compositions were found on wall niches, pillars of the nave, apses and domes. Similar paintings were to be found in necropolis such as the necropolis of Al Bagawat in Kharga Oasis. The most famous monasteries which were richly decorated with Coptic wall paintings and symbols are Bawit, Saqqara, Kellia, and in hermitages such as Isna. ${ }^{2}$

\section{Importance of the Coptic wall painting}

In general Coptic wall paintings had two main functions, the first one is that they played the role of story tellers which were very affective because they were clear, direct and simple and the second one is that they acted as an architectural decoration. $^{3}$

\section{Egyptian wall painting Historical Development}

The paintings of the early Egyptian history were divided into two main branches: the mural paintings and carving on different materials. ${ }^{4}$ The only surviving example of tombs dating back to the predynastic period is at Hieraknopolis ${ }^{\mathbf{5}}$, the paintings on the wall of its tomb reflect the power of Egypt to face any intruders especially from the south. ${ }^{6}$

Paintings in the Old Kingdom the scenes of this period were religious scenes and daily life scenes in which the owner engaged in his daily life activities also, scenes of sowing, fishing, and hunting were depicted in details .these scenes in many cases were accompanied by hieroglyphic inscriptions to protect the owner against any danger. ${ }^{7}$ In the religious scenes, the owner was depicted looking after the preparations

${ }^{1}$ Stifes, R., The Arts and Man, New York, 1940, p. 322-326.

${ }^{2}$ Severin, H.G., in Beradino, A.(ed.), Encyclopedia of the early church, London 1992, volume I, P. 267-268.

${ }^{3}$ Gombrich, E. H., The story of Art, London, 1950, P. 37-39.

4 Emery, W.B., Archaic Egypt, London, 1961, p.10-20.

5 Hieraknopolis was considered the most southern region of Egypt separating it from Nubia, which was discovered by Green. Smith, W.S., History of Egyptian Sculpture in the Old Kingdom, New York, 1978,p.123-126.

6 Case, H., \& Payne, J.C., JEA 48, London, 1962, 11-18.

${ }^{7}$ David, R.A., The Ancient Egyptians, London, 1982, pp., 80-84. 
of the funeral festival. The scenes in each tomb differ in their number and themes. They were prepared during life time of the owner, the artists worked under his direct control. ${ }^{1}$ The colors for the figures are limited varying between yellow, reddish brown, yellowish brown and white pigment while, the blue green for the hieroglyphs and red for the outlines. ${ }^{2}$ The tomb paintings of the second half of the third dynasty is characterized by depicting every object in its actual size ${ }^{3}$, new scenes were introduced and were elaborated by adding details. The function of these details were fill empty space and to give more information about the subject of each scene.

The style of mural paintings used in the Old Kingdom was revived in the Middle Kingdom but with the addition of new elements. However, the subject matter of the scenes was nearly the same. Tombs of Beni Hassan are the best example of the development of mural paintings. ${ }^{4}$

Paintings were used alongside the carving in the Old Kingdom and partly the Middle Kingdom, but from the Middle Kingdom onwards, painted scenes were considered the main theme of most of the architectural buildings. , mural paintings were applied mainly in the rock cut tombs for The best source of the Egyptian wall paintings during the New Kingdom is the private tombs of the Theban Necropolis, where they all share a similar style of paintings, the figures represented with clear outlines, the backgrounds are pale bluish gray and the others are blue yellow, pink and brick red which are all clear in light and tone. ${ }^{5}$

The idea of space had changed in the Amarna period; each wall was considered a unit by itself. The main difference from the previous Theban tombs is that the corner line separating the walls was completely plain, while in the Theban tombs it was adorned with decorative patterns. ${ }^{6}$

After the fall of the Amarna Period, the earlier funerary scenes began to be replaced by much more religious scenes such as those representing goddess Hathor offering life to the dead, during this period mural paintings were influenced by both the political and economic situations of the country. Paintings began to decline in the Ramasside period except during the reign of Seti I, the scenes contain lively colors, well depicted bodies, and realism derived from the Amarna style of art. The art of

${ }^{1}$ Budge, E.A., Wall Decorations of Egyptian Tombs, London, 1914, p. 3-5.

${ }^{2}$ Romano, J.F., \& Robins, G., JARCE 31, Cairo, 1994, pp. 25-27.

${ }^{3}$ Petrie, F., The Marking of Egypt, London, 1939, pp. 106-107.

4Brazilller, G., \&Terrace, E.L.B., Egyptian Paintings of the Middle Kingdom, New York, 1967, pp. $42-47$.

${ }^{5}$ More than half of these tombs were designed during the life time of Queen Hatchepsuet and Thutmosis III. The others belong to the reign of Amenhotep II, Amenhotep III and Thutmosis IV.

Hayes, W., The Scepter of Egypt. A Background for the Study of Egyptian Antiquities the Metropolitan Museum of Art, Cambridge, 1959, pp. 163-167.

${ }^{6}$ Aldred, C., in Schmandt, B. D., (ed.), Immortal Egypt, USA, 1978, 1978, 56-60. 
painting continued its decline until the late period when there is hardly any evidence of mural paintings. ${ }^{1}$

After the end of the Ramasside period, there was a decline in the standard of art. Mural paintings became rare while small wooden panels became popular.

During the $25^{\text {th }}$ dynasty the Ethiopian influence began to develop, painting on papyri flourished, and they were mostly religious scenes. In this period, Greek art was introduced for the first time to Egypt through commercial relations. The Greek influence appeared mainly on sculpture.

The Paintings in the Graeco Roman Period In the Alexandrian mural paintings there were mainly two main styles; royal and private. The subject matters were not only purely religious but also of philosophical themes. The painter started to draw his symbols and subjects from the daily life and nature scenes, also women started to be depicted with all their female features. The method used for the mural paintings was mainly identified in the Roman world as the Pompein Style. ${ }^{2}$

The mural paintings played elementary two roles inside the Coptic architecture; first the decorative role where scenes were employed to be comfortable vision for visitors, the second role is the functional role in which the scenes were used to be represented inside especial parts of the Coptic architecture like monastic fortress "protector angel", the chapel and choirs "apocalyptic visions

The art of Coptic wall painting scenes can be divided into two periods

The first period from the first century till the mid of the fifth century The Old Testament Stories of the Jew's prophets was one of the important features of the wall paintings topics, like Adam and Eve, Abraham and Isaac (Abraham's sacrifice), Daniel in the lion's Den, David at the court of Saul, and Jonah and the whale. 3 The second periodWhich extended from the middle of the $5^{\text {th }}$ century till the mid of the seventh century Depicted painting topics inspired from the Gospels' of Matthew, Mark, Luke and John which were arranged by historical order, also inspired from Epistles of Paul the Apostle. ${ }^{4}$

Ancient Egyptian reliefs were covered with layers of plaster and Christian themes were painted on the stucco base (like the Tomb of Pinches - Tel al-Amarna Al-Minia). These wall-paintings survive "in situ" in some places in Egypt.

${ }^{1}$ Groeneewegen, F.H.A.,\& Ashole, B., Ancient World From Egypt Mesopotamia and Crete, NewYork, 1987, 77-91.

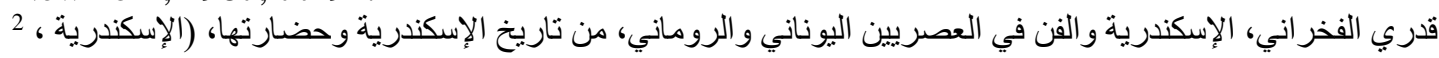
135-131 1963 Pompein: A word driven from the name of the city of Pompey near Napoly which was destroyed in 79 A.D.

${ }^{3}$ Znutz, D., The two styles of Coptic painting ,JEA 21, 1935, p.63.

Znutz, D., Opcit, p.66. ${ }^{4}$

Bourguet ,P., Coptic Art, ,London, 1971, pp. 12-14. ${ }^{5}$ 


\section{The architectural influence of the ancient Egyptian art on Coptic wall painting:}

The architectural impact of the ancient Egyptian temples was the main motivator for the design of the Coptic Church, as the first Christians used the ancient Egyptian temples and cemeteries as houses and cult centers according to their traits of reverence, holiness and the high feelings in terms of spiritual context. Both saints, Antonio and Pola lived inside the ancient Egyptian tombs, other Christian traces were found in the tombs of El-Amarna, Beni Hassan, and Abydos. ${ }^{1}$ The Christian building followed the planning of ancient Egyptian architecture as the temple was being divided into three divisions beginning with a courtyard followed by a hall of columns and ending with the holy of hollies. ${ }^{2}$ There are three adjacent churches carry what indicate their affiliation to the first stage of the Christian age: the hanging church, Abu Serja church, and the church of St. Barbara. These three churches, though their Basilica from, are closely connected with the ancient Egyptian temples. ${ }^{3}$

The three churches divided into: the entrance corridor, a courtyard with its aisles then the sanctuary, ${ }^{4}$ what was called in the ancient Egyptian temples as the holly of hollies. ${ }^{5}$ In the church of Anba Armia in Saqqara, there is an architectural phenomenon because of its adjacency to the Egyptian temples, as this church was built higher than ground level, it could approach by a staircase adjoining the wall which was a known ancient Egyptian system in the mortuary temples. ${ }^{6}$

\section{Results and Discussion}

The Coptic wall painting influenced by the ancient Egyptian tradition in the proportions and dimensions, particularly for the human forms that were represented adjacent or behind each other. In the ancient Egyptian art, the painted human form in the closer level was taking the scales of the human form to the furthest level, representing one of the human forms lager than the other one behind it, indicates the importance of the figure that was represented on a larger scale. ${ }^{7}$

As the ancient Egyptian art neglected the representation of the deep dimension and the prospective rules The Coptic artist neglected, as well, the depth and the prospective rules. ${ }^{8}$ He used the non-prospective vision that depends on the superficial representation of the themes, with keeping the contents and the purpose; this is clear

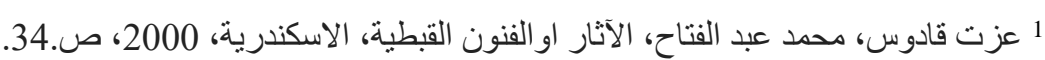

$$
\begin{aligned}
& 2 \text { تحفة حندوسة، التراث الفرعوني في الفن القبطي، مقالة في ندوة لجنة التاريخ و الآثار بالمجلس الأعلي للثقافة، }
\end{aligned}
$$

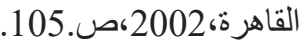

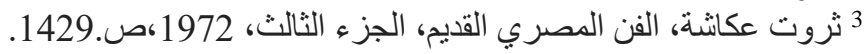

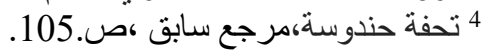

$$
\begin{aligned}
& 5 \text { باهور لبيب، العصور المسيحية الاولي، الفن القبطي، موسوعة محيط الفنون، القاهرة، 1971، صني، ص. } 15 .
\end{aligned}
$$

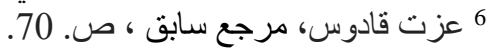

$$
\begin{aligned}
& 7 \text { مني بدر ، اثر الفن القبطي علي الفن الاسلامي في التحف المنقولة، رسالة ماجستير ، كلية الاثار ،جامعة القاهرة، } \\
& \text { 47-4601980 }
\end{aligned}
$$

${ }^{8}$ Gruneisen, W. de. ,Caracteristiques de l'art Copte, Florence,1922, p.34. 
in the paintings of the 'Chapel of the Exodus' in Bagawat, which contains the themes of the flight of the children of Israel from Egypt. ${ }^{1}$

The Coptic artist used, as well, some symbols of the ancient Egyptian gods such as the scepter that symbolizes the authority for the Egyptians, in addition to being a symbol for god Osiris (Figure1), the god of other life. ${ }^{2}$ He used also the Ankh sign that means life for the Egyptians, and has a great significance for Christians, as it symbolizes the Christ during his life and crucifixion as Coptic people adopted it as a symbol and emblem for them (Figure 2) ${ }^{3}$, because of the matching between both signs in form and meaning as both of them symbolizes the life. This indicates the correlation of the public life with the Coptic wall painting. Then, the Ankh sign(Figure 3) developed and implied in the cruciform, as a sign of life and light, this was found in the personification of peace in Bagawat ${ }^{4}$.Some Christians claimed that the ancient Egyptian statues hold this sign to glorify the religion of future, the Christianity. ${ }^{5}$

The Coptic wall painting influenced by the ornamental elements of ancient Egypt that formed from crossed circles which considered between the oldest geometric ornamental elements and the most common, and the zigzag lines such as the common ornaments in the tombs of Thebes. From the Egyptian elements that continued in the Coptic wall, painting is the decorated bands, rosettes, spiral maritime shells. (Figure 4) ${ }^{6}$

The ancient Egyptian influence could be shown, as well, in the painted friezes between two borderlines, which was a well-known Egyptian style in the ancient Egyptian paintings, while the artist in Bawit chose scenes from the Prophet David's life to look independent inside the lined frame, and ornamental floral and geometric units divided these frames. (Figure 5) ${ }^{7}$ The ornaments of the column capitals derived also from Egyptian elements such as grapes, grape leaves, and palm leaves. ${ }^{8}$

The emergence of Coptic art in the atmosphere of the Roman-Hellenistic arts in Egypt never denied the trend towards the ancient Egyptian roots. Some themes continued ${ }^{9}$ which imitated some stable and known things in the ancient Egyptian $\operatorname{art}^{10}$ in the

${ }^{1}$ Gabra, G.and Vivian, T. Coptic Monasteries: Egypt's Monasteries: Egypt's Monastic Art and Architecture, Cairo, Amirican University in Cairo Press, 2002, p. 24.

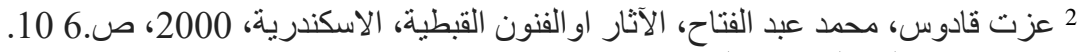

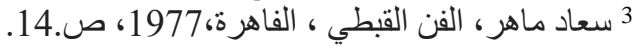

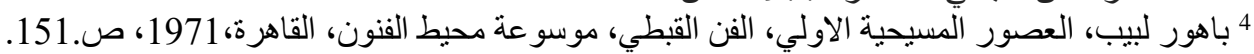

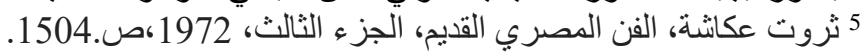

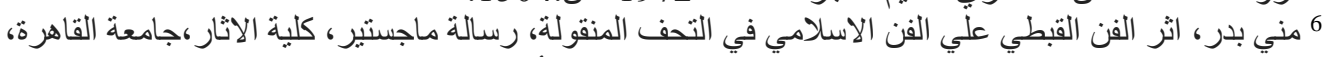

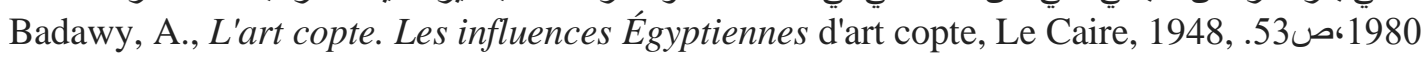


Nomes of middle and Upper Egypt, which kept many traditions and religion believes in front of the Roman and Greek flows. Whenever we go southward, we can find the impact of the pure Egyptian spirit in the Coptic art in general and in Coptic wall painting. ${ }^{1}$

From the themes that the Coptic artist inspired from the ancient Egyptian thought: the belief of judgment and punishment (Figure6) which painted by the artist on the walls of the chamber number 12 in Bawit, the scenes of angels punishing the bad people, and the theme of justice that represented in the peace chamber in Bagawat. As Coptic's thoughts were not away from the thoughts that the ancient Egyptian adopted, the Coptic artist was inspired by some of these thoughts in which he found a way to illustrate his new ideas. ${ }^{2}$

Of the most important inherited ideas from the Egyptian heritage: the triumph story of good over evil that represented in the form of Horus and his victory over Seth, evil god, and liberating people from his injustice. ${ }^{3}$ (Figure7)The Coptic artist used this myth to express the Jesus Christ, the victorious over evil, who was sent to fight the paganism and to get over it, and it is clear in the high reliefs in louver museum in Paris which dated by Du Bourguet to the $4^{\text {th }}$ century A.D. ${ }^{4}$

In addition to that, the theme of motherhood that represented in the scene of Virgin Mary and her infant that recalls goddess Isis carrying her baby on her knees, and the painting of Virgin Mary breastfeeding the Christ that imitates the role of Isis. (Figure8) ${ }^{5}$.

\section{Conclusion}

The strongest evidence that the art is a real translation of the Egyptian life during that time, and that it is considered one of the stages of the Egyptian art, what means that it was found according to the inherited Egyptian artistic traditions, it was termed the Coptic art or the Egyptian art. ${ }^{6}$ Hence, almost all the archaeologists agree that the ancient Egyptian art had its influence on the Coptic wall painting in Egypt, as Soad Maher argues that the themes of the Coptic wall painting in Egypt are derived from two sources: the ancient Egyptian influences and the religious Christian stories. ${ }^{7}$ Gruniesen, ${ }^{8}$ Tharwat Okasha ${ }^{9}$ and Talbot Rice ${ }^{10}$ support this theory as the Christian Egyptian used this art to ensure his Egyptian nationality and his liberty from the Roman foreign rulers and the cultured Roman category. Then, the Christian

$$
\begin{aligned}
& 1 \text { مر اد كامل، حضارة مصر في العصر القبطي،القاهرة، ص. } 134 . \\
& 2 \text { عزت قادوس، محمد عبد الفتاح، الآثار او الفنون القبطية، الاسكندرية، 2000، صنوكن، 109،102،102. }
\end{aligned}
$$

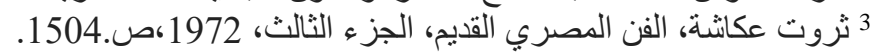

${ }^{4}$ Bourguet,Du., Coptic art, London, 1971, p.95,pl.78.

5 ثروت عكاشة، مرجع سابق ،صو.1504.

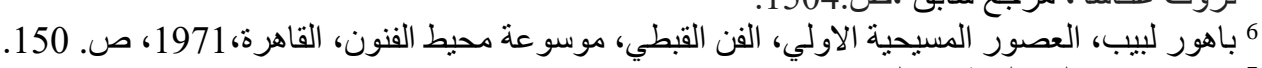

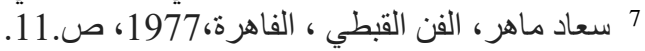

${ }^{8}$ Gruneisen, W. de. ,Caracteristiques de l'art Copte, Florence,1922, p.30.

10 Talbot Rice, Byzantine Art, London,1968, p.49

$$
9 \text { ثروت عكاشة، مرجع سابق ،ص.1429. }
$$


religion was used to express the personality of the artist and his independence by using an art has its own ancient Egyptian flavor. ${ }^{1}$

Nevertheless, the Christian Egyptian art is a stage of the general stages of the Egyptian art, based on Christianity and derived from the Egyptian civilized artistic heritage throughout the preceding periods. In addition to the general impacts that influenced, directly or indirectly, on this artistic course, as the Egyptian artist adopted them and found his own art, as an original art with high status and singularity ${ }^{2}$ full of the aesthetic values that resemble the recent artistic values what imposed its presence, and modernity, ${ }^{3}$ in addition to that the cultured Egyptian sense knew how to achieve the mutual influence with others what resulted in unity in different arts, what could be termed as conversation between civilizations.

\section{Bibliography}

-Aldred, C., in Schmandt, B. D., (ed.), Immortal Egypt, USA, 1978.

- Badawy, A., L'art copte. Les influences Égyptiennes d'art copte, Le Caire, 1948.

-Bourguet ,P., Coptic Art, ,London, 1971.

-Brazilller, G., \&Terrace, E.L.B., Egyptian Paintings of the Middle Kingdom, New York, 1967.

-Budge, E.A., Wall Decorations of Egyptian Tombs, London, 1914.

-Case, H., \& Payne, J.C., JEA 48, London, 1962Emery, W.B., Archaic Egypt, London, 1961.

-David, R.A., The Ancient Egyptians, London, 1982.

-Gabra, G.and Vivian, T. Coptic Monasteries: Egypt's Monasteries: Egypt's Monastic Art and Architecture, Cairo, Amirican University in Cairo Press, 2002.

-Gombrich, E. H., The story of Art, London, 1950,

-Green. Smith, W.S., History of Egyptian Sculpture in the Old Kingdom, New York, 1978.

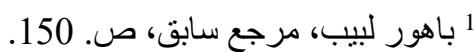

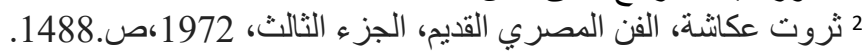

$$
\begin{aligned}
& 3 \text { مني بدر، اثر الفن القبطي علي الفن الاسلامي في التحف المنقولة، رسالة ماجستير، كلية الاثار ،جامعة القاهرة، }
\end{aligned}
$$

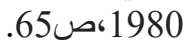


-Groeneewegen, F.H.A.,\& Ashole, B., Ancient World From Egypt Mesopotamia and Crete, New York, 1987.

-Gruneisen, W. de. ,Caracteristiques de l'art Copte, Florence,1922.

-Hayes, W., The Scepter of Egypt. A Background for the Study of Egyptian Antiquities the Metropolitan Museum of Art, Cambridge, 1959.

-Petrie, F., The Marking of Egypt, London, 1939.

-Romano, J.F., \& Robins, G., JARCE 31, Cairo, 1994.

-Stifes, R., The Arts and Man, New York, 1940.

-Severin, H.G., in Beradino, A.(ed.), Encyclopedia of the early church, London 1992, volume I.

-Talbot Rice, Byzantine Art, London, 1968.

-Weasel, K, L'art Copte, L'art Antique de La Basse Époque en Egypt, Brussels 1964.

- Znutz, D., The two styles of Coptic Painting, JEA 21, 1935.

$$
\begin{aligned}
& \text {-باهور لبيب، العصور المسيحية الاولي، الفن القبطي، موسوعة محيط الفنون، القاهرة، } 1971 \\
& \text { ـتحفة حندوسة، التزراث الفرعوني في الفن القبطي، مقالة في ندوة لجنة التاريخ و الآثار بالمجلس الأعلي للثقافة، }
\end{aligned}
$$

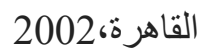

$$
\begin{aligned}
& \text { - مروت عكانثة، الفن المصري القديم، الجزء الثالث، } 1972 \\
& \text { - سعاد ماهر ، الفن القبطي ، الفاهرة،1977، } \\
& \text { ـ عبدالرحمن السروجي، در اسة علاج وصيانة الايقونات القبطية تطبيقا علي ايقونات من بعض متاحف وكنائس } \\
& \text { و اديرة الوجه البحري ، رسالة ماجيستير ،كلية الاثار ،جامعة القاهرة، } 1997 \\
& \text { - فريد شافعي، العمارة العربية في مصر الاسلامية،القاهرة،1994 }
\end{aligned}
$$

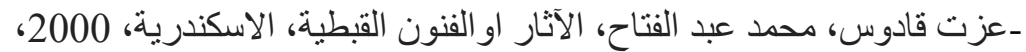

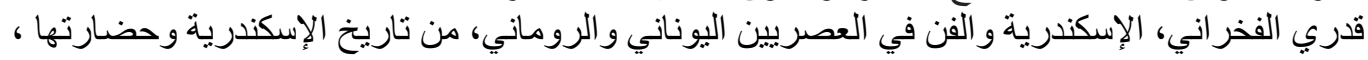

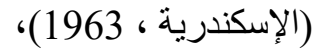

$$
\begin{aligned}
& \text { ـمر اد كامل، حضارة مصر في العصر القبطي،القاهرة، } \\
& \text { مني بدر، اثر الفن القبطي علي الفن الاسلامي في التحف المنقولة، رسالة ماجستير ، كلية الاثار جامعة }
\end{aligned}
$$

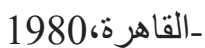


Received: April 2020

Accepted: June 2020 